\title{
THE SUSTAINABLE URBAN DISTRICT OF VAUBAN IN FREIBURG, GERMANY
}

\author{
G. J. COATES \\ School of Architecture, Kansas State University, USA.
}

\begin{abstract}
The university town of Freiburg, Germany has a well-deserved reputation as the European capital of environmentalism and sustainable architecture and urban design. The city is perhaps best known for the development of two model sustainable urban districts, Rieselfeld and Vauban, both of which integrate multi-modal transportation linkages, ecological storm water management, low-energy passive solar houses, combined heating and power (CHP) systems, mixed uses (both public and private), local schools and a variety of shops to meet everyday needs, thus reducing greatly the need for private car ownership.

The focus of this paper is on Vauban, a mixed-use district of some 5,100 residents, which has been built on the site of a former French military base. Unlike Rieselfeld and most other European sustainable urban districts, Vauban grew from the grass roots up and was largely designed and developed (within city guidelines and with technical assistance provided by the city) by many Baugruppen, small ecologically and socially progressive homeowner cooperatives organized under the auspices of the Vauban Forum. Members of each Baugruppe worked with their chosen architect to design their own apartments and housing blocks as well as their shared outdoor living spaces. The result is a community that is socially cohesive and architecturally diverse. Excellent light rail connections to all of Freiburg, as well as car sharing clubs and extensive walking and bicycle paths, offer Vauban residents everything they need for everyday life without owning a car. In addition to pioneering new patterns of user-developed ecological urban design, Vauban also has been a leader in setting new lowenergy standards for buildings in Freiburg as well as for the rest of Germany.

Based on a review of the literature, interviews with selected architects and residents as well as on-site observations by the author, this paper presents a comprehensive description of Vauban as a successful example of participatory design and development, as well as social, economic, architectural and technological sustainability.

Keywords: Baugruppen, biophilic design, 'car-free'living, carbon neutral building design, child-friendly urbanism, combined heat and power systems, design for social diversity, ecological storm water management, participatory planning, Passivhaus and Plusenergie ${ }^{\circledR}$ housing, solar photovoltaics, sustainable urban design.
\end{abstract}

\section{VAUBAN: AN OVERVIEW}

Construction of the sustainable urban district of Vauban started in 1998 and continues to the present. It is built on a 94 acres site that was a former French military base located at the southern edge of Freiburg, two miles from the historic Old Town. At present, Vauban is home to nearly 5,100 residents, living in some 2,000 dwelling units (Fig. 1). In addition to offering varied housing options for a diversity of family needs, Vauban provides a complete range of shopping for everyday life as well as a large array of professional services. Altogether, there are some 600 jobs in the district, all of which can be easily accessed on foot or by bicycle. With connections by light rail and bus, as well as by walking trails and bike paths, to the rest of the city and the main train station, Vauban is an integral part of the larger city and region.

From the beginning of its planning phase in 1993, Vauban has received national and international recognition and awards as an example of the state of the art in sustainable urban design. In 1996, Vauban was chosen as a "best practice" example of citizen participation in 'urban development', representing Germany at the United Nations Conference on Human Settlements in Istanbul. In 2002, Vauban and the city of Freiburg as a whole were given the Dubai International Award for best practice as part of the United Nations Human Settlements Program. More recently, in 2010, Vauban 


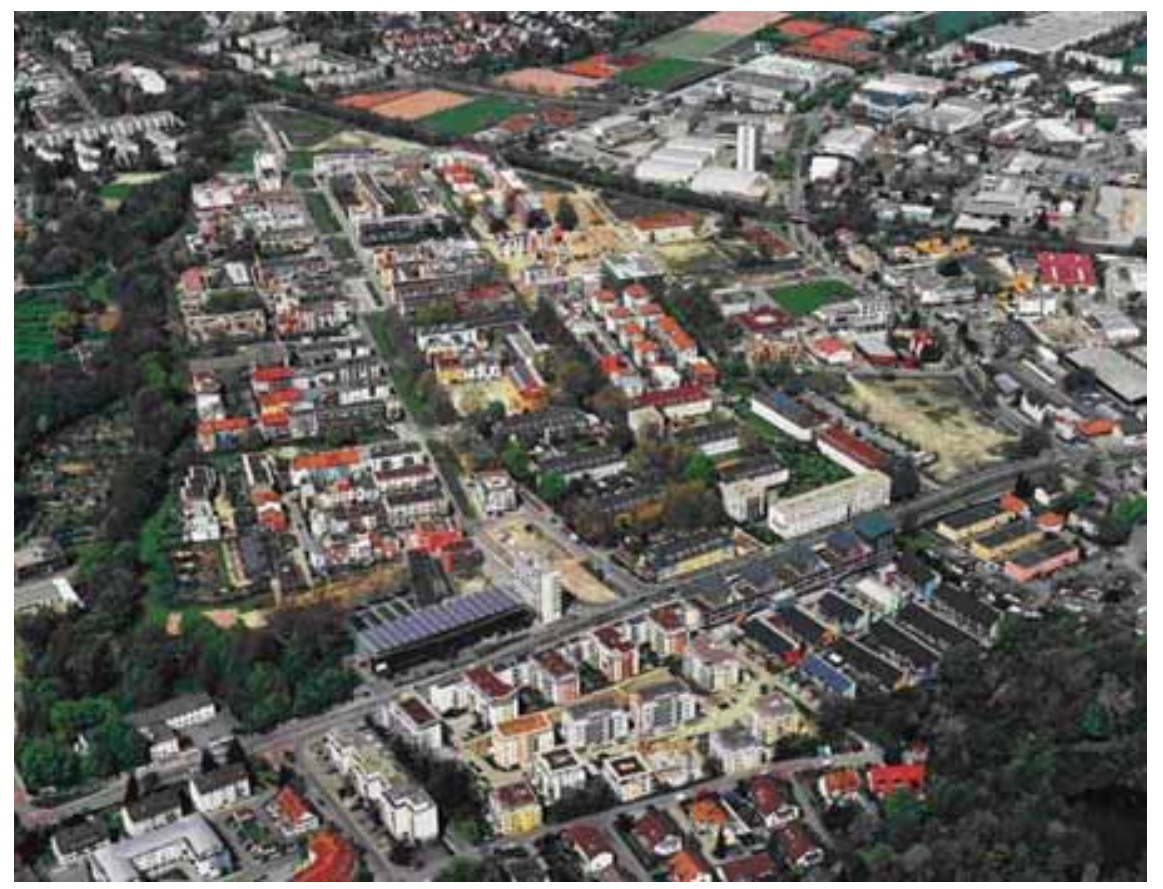

Figure 1: Aerial view of Vauban.

was featured at the 'Better City-Better Life' Exposition held in Shanghai [1]. Every year Vauban is visited by tens of thousands of people from all over the world, including planners, architects, city administrators, students and ordinary citizens, who come to learn about and experience a community that they see as being ecologically, socially, economically, architecturally and technologically sustainable.

Vauban, like any built environment, is the tangible product of historically situated processes. To understand this district, therefore, it is necessary to follow its life-history, starting from the beginning.

\section{THE PLANNING AND DEVELOPMENT PROCESS}

Following the fall of the Berlin wall in 1989 and the reunification of Germany in 1990, French armed forces withdrew from their garrison in Vauban. Ownership of the district reverted to the German federal government and the City of Freiburg purchased it for some EUR 20 million. Because of the serious housing shortage in Freiburg at the beginning of the 1990s, the city decided to develop the site as a new sustainable urban district, creating a development corporation to plan the site, prepare infrastructure and oversee development of the project.

In 1993 students and ecologically and socially minded citizens, many of whom had participated in anti-nuclear protests going back to the late 1970s and early 1980s, began to meet informally to share their hopes that Vauban might be developed by means of a participatory process as an ecologically friendly, highly energy efficient, solar powered and largely car-free urban community. Soon thereafter they began to convert their dreams into reality.

Development of the former military base began in 1994 when the University of Freiburg's Student Services Department began to convert six barracks into student apartments. Members of another 


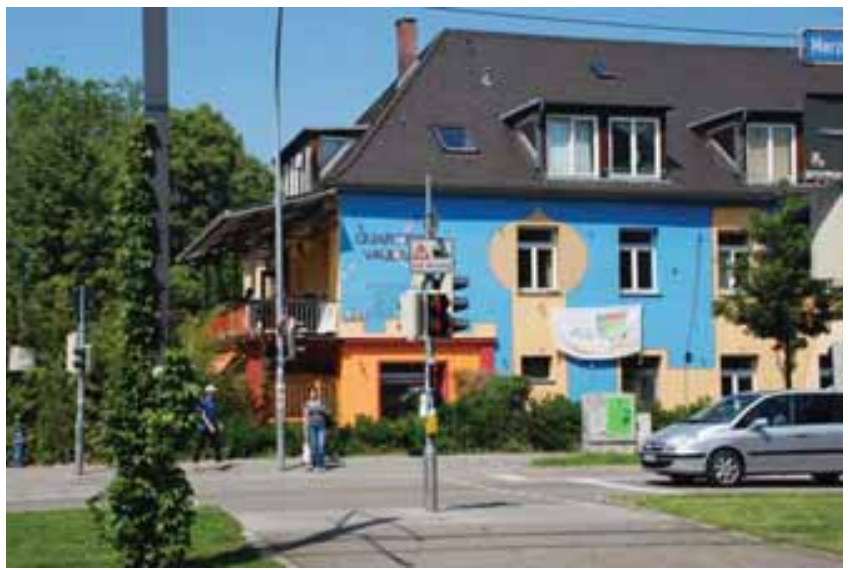

Figure 2: SUSI housing in former barrack along Merzhauserstrasse.

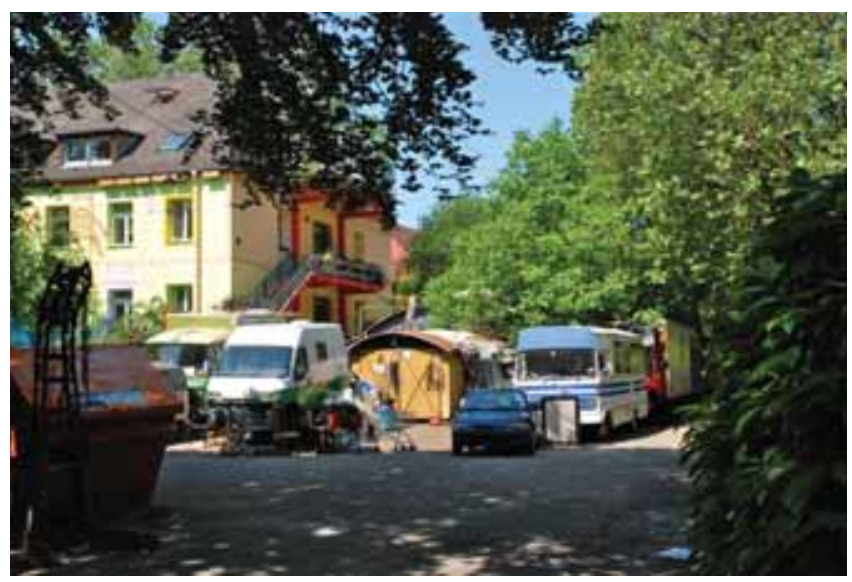

Figure 3: 'Box Car' village as part of SUSI self-managed housing.

group, the Independent Settlement Initiative (SUSI), founded at the end of 1990, also made known their intention to develop an alternative housing community on the site. Therefore, conflict between activist citizens and the city was at the origin of the Vauban development. A compromise was reached that allowed SUSI to rent and eventually purchase four barracks, but this was not the end of the issues the city had to face (Fig. 2). Ever since the French troops moved out, the property had become home to around 100 squatters, called 'box-car dwellers'. While some of these unwanted residents were removed by police, others were eventually integrated into the SUSI project, giving Vauban an architectural and social diversity that it never would have otherwise had (Fig. 3). While the student housing and SUSI communities are technically within the Vauban development district spatially, they were only included within the development plans as an already existing quarter [2].

The city continued to work with grass-roots leaders, and at the end of 1994 established Forum Vauban with five paid staff members. The goal of this organization was to facilitate expanded citizen participation in both the planning and development of the district. 
With the main goals being set by the city by the end of 1994, a competition was held for the design of Vauban. All entrants were to provide a master plan for a high-density housing district that would include spaces for small businesses as well as public services infrastructure including schools, kindergartens and recreational areas. Bicycle paths and sidewalks were to be given priority over automobiles and the city's light rail line was to be extended into the heart of the community to link the district to the city center. Environmental standards were also established by the city, requiring houses to be built to German low-energy standards or better. Building construction systems were required to be durable and of high quality. It was also decided that the district would be provided with electricity and hot water by a wood-pellet-fired combined heat and power (CHP) plant. All proposals were required to preserve existing trees and other natural features including the creek running at the edge of the southern boundary of the site. Finally, the designs for Vauban were required to have an ecologically based system for catching and retaining rainwater on site. Altogether, the vision was for Vauban to be developed as an 'urban garden'.

The competition was won in 1995 by the team of Kohlhoff and Kohlhoff, architects, Luz and Partners, landscape architects, and Hans Billinger, transportation planner, all based in Stuttgart (Fig. 4). With this basic design in place, the city invited citizens to actively participate in the further development of the new quarter under the auspices of Forum Vauban. The Forum then formulated its own goals and began organizing citizens for greater participation. One result of this power-sharing process, however, was another conflict. The Forum strongly advocated goals not originally formulated by the city and, in addition, put forward a proposal for a self-administered community center with offices for various organizations as well as a locally owned restaurant. This idea involved saving and renovating one of the former barracks and the creation of a plaza in front of this proposed 'city hall' to be used for farmers markets, flea markets, and various community gatherings. In making these proposals, it was clear that future residents of Vauban felt it essential that there be a shared social area at the heart of the community. To meet this demand, the city agreed to forgo the profits from the sale of this property.

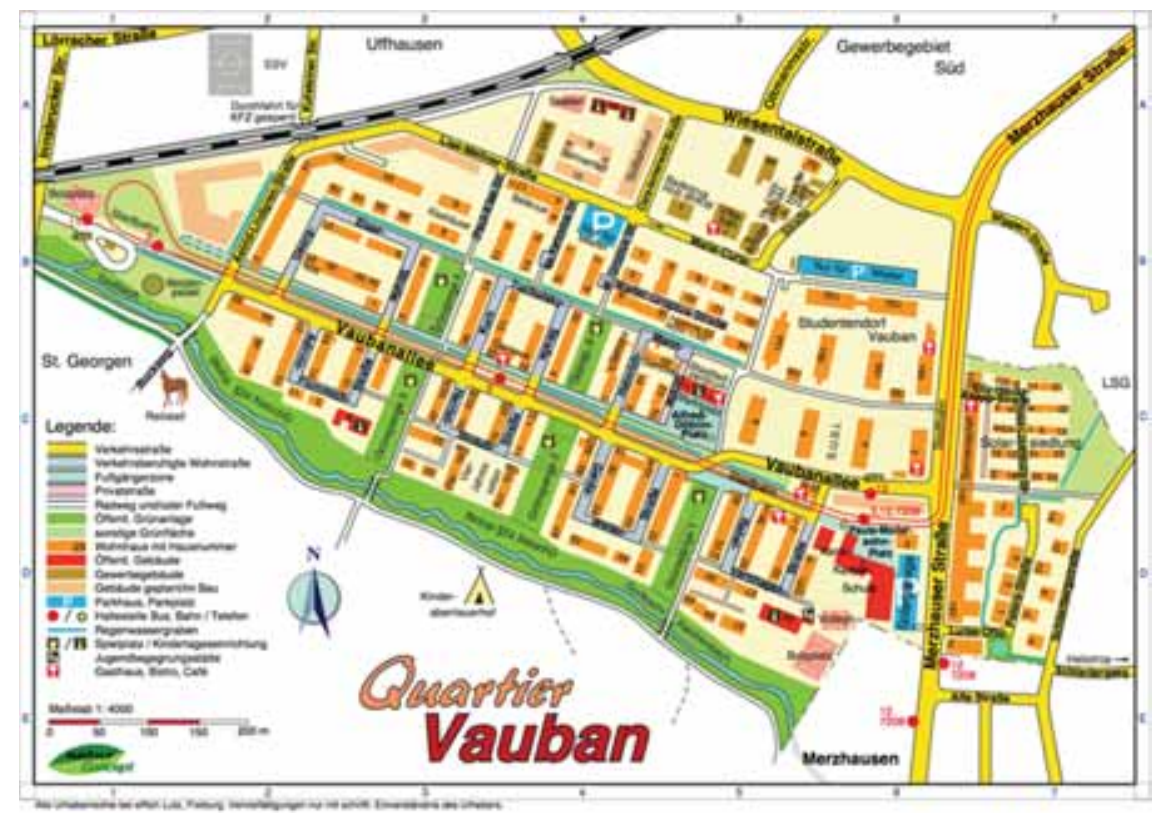

Figure 4: Vauban site plan. 
In addition, Forum participants felt that the district's energy concept did not go far enough. In response, the city allocated more sites for passive houses. Finally, citizens insisted on the implementation of their original idea of creating a 'car-free' district, a demand that required the city to resolve a number of statutory and legal issues [3].

\section{URBAN DESIGN}

The final master plan was derived from the layout of the old military garrison. Vaubanallee, a central avenue running roughly east-west through the center of the district, connects to Merzhauserstrasse, which is the main automobile and light rail corridor connecting the center of Freiburg with the rural countryside to the south. The light rail line in Vauban runs down this corridor and is set in a grassy swale in order to muffle sound and contribute to the district's overall ecological storm water management system (Fig. 5). Automobile, pedestrian and bike paths also run along this central corridor and it is lined on both sides by local businesses (Figs $6 \& 7$ ).

Opening off the pedestrian and bike paths that line the north edge of Vaubanallee is Alfred-DöblinPlatz, the central square in front of Haus 37, the former barrack converted into a community center (Fig. 8). Also to the north of Vaubanallee are: sites for future housing; the CHP plant; additional housing (including social housing), and more retail space and a small business incubator. While not a formal part of the Vauban development, the area north of Vaubanallee also includes the student housing village, the SUSI housing units and an area for the former squatters to continue living in their box car village.

Branching off Vaubanallee, both to the north and south, are seven neighbourhoods framed by 4- to 5 -storey housing blocks (net density of 95 units/ha) built around narrow U-shaped 'play streets', which cannot be used either for traffic or for parking (Fig. 9). Only deliveries and service vehicles are allowed, and even then vehicles must be driven at a walking pace [4].

These neighborhoods are separated (and also joined) by five resident designed parks running roughly north-south that connect with the walking trail along Dorfbach creek, a natural area bordering the south edge of Vauban (Figs $10 \& 11$ ). Not only do these parks serve as play and recreational

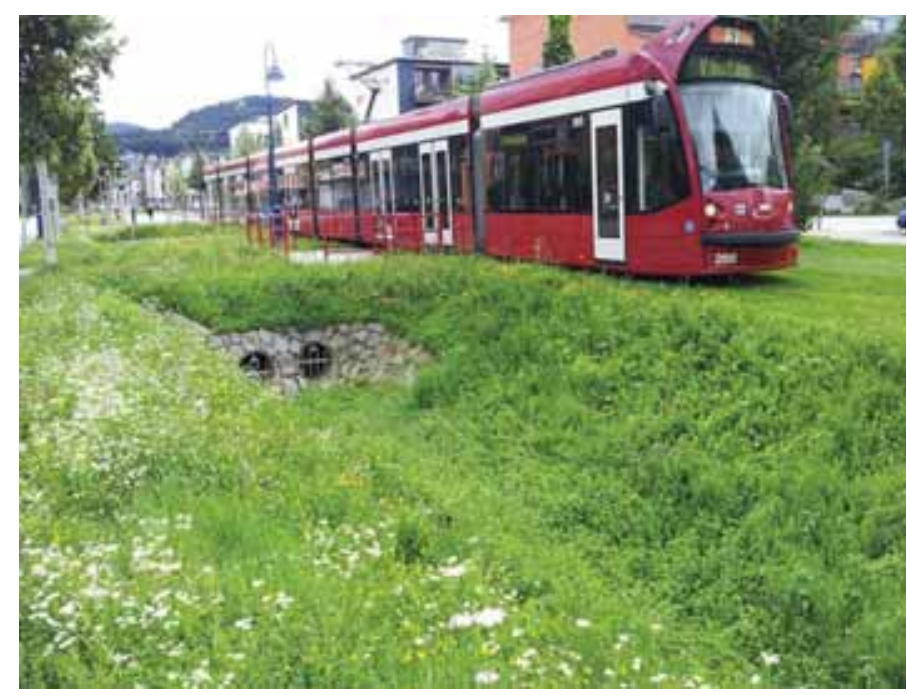

Figure 5: Vauban's light rail tracks are set in a green bio-swale. 
areas that provide visual connections to the rural landscape beyond but they also serve as ventilation corridors, bringing cooling breezes from the hills to the south into the heart of the whole district [5].

While it is not formally a part of Vauban, a number of child-oriented educational opportunities are located close at hand along Dorfbach creek, including an adventure playground and an interactive animal park, with horses, sheep, pigs rabbits and chickens that children can care for under expert adult supervision. This 'wild' southern edge of Vauban is also lined by a number of Passivhaus blocks that look onto the creek (Fig. 12). Here, and throughout Vauban, with its many public parks, numerous mature trees and extensive private gardens, one has the sense that, in spite of its density, nature is always near [6].

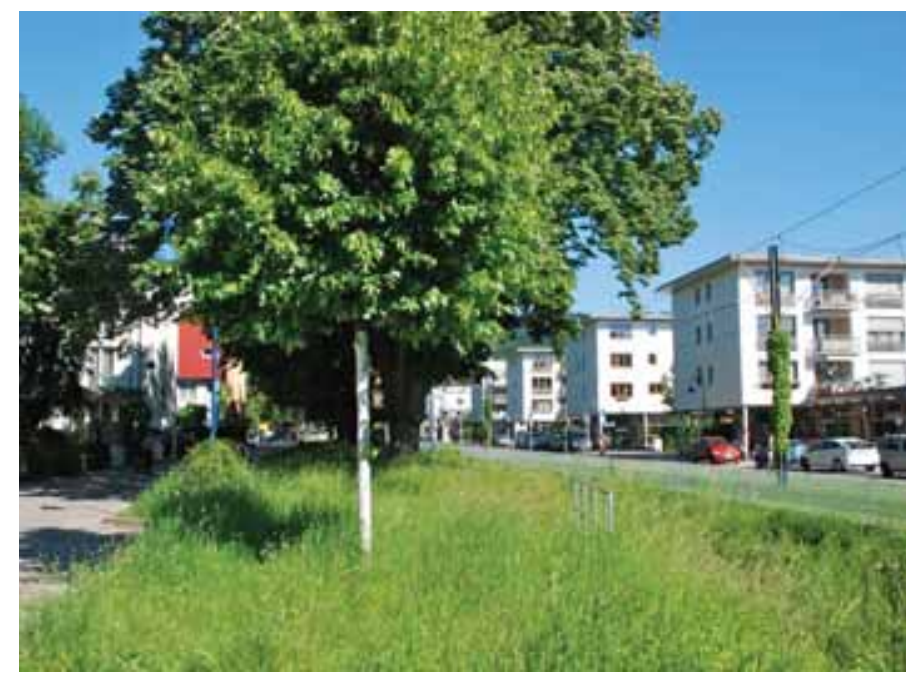

Figure 6: Bicycle and pedestrian paths run along the light rail tracks.

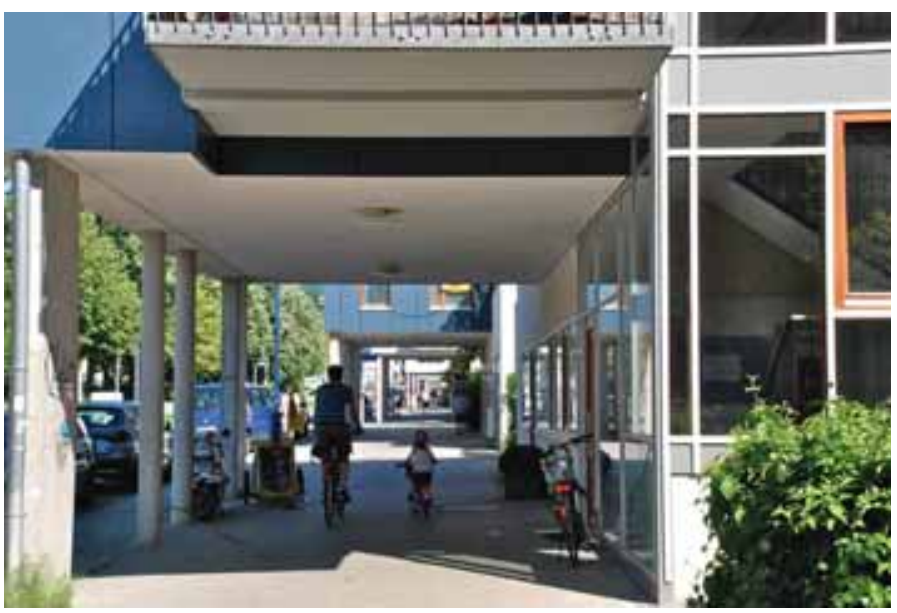

Figure 7: Arcaded shopping street on southern edge of Vaubanallee. 


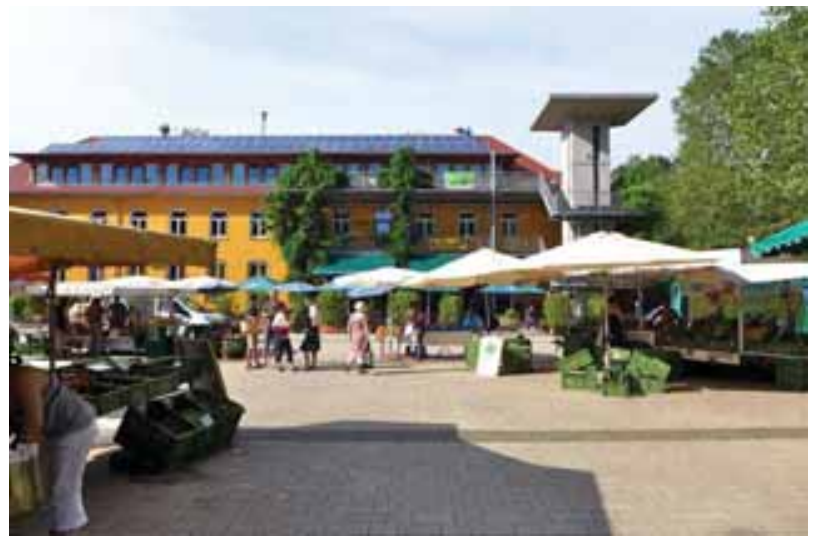

Figure 8: Haus 37 and Alfred-Döblin-Platz.

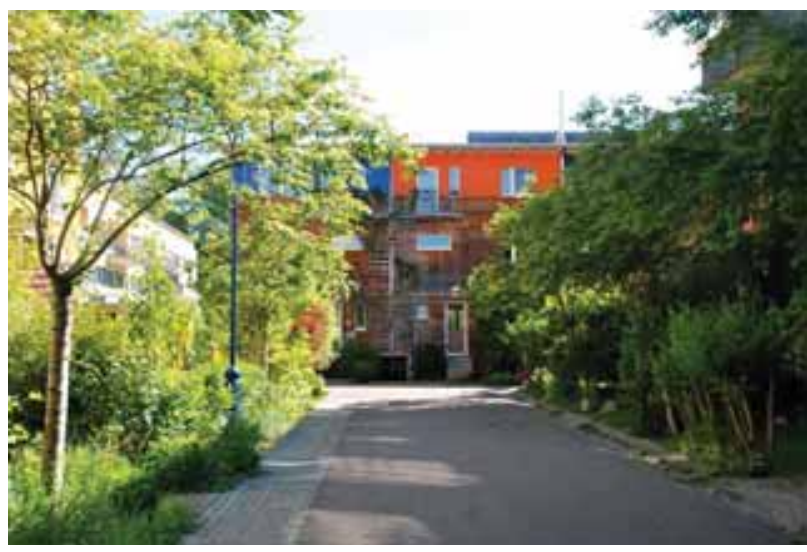

Figure 9: Residential car-free 'play street'.

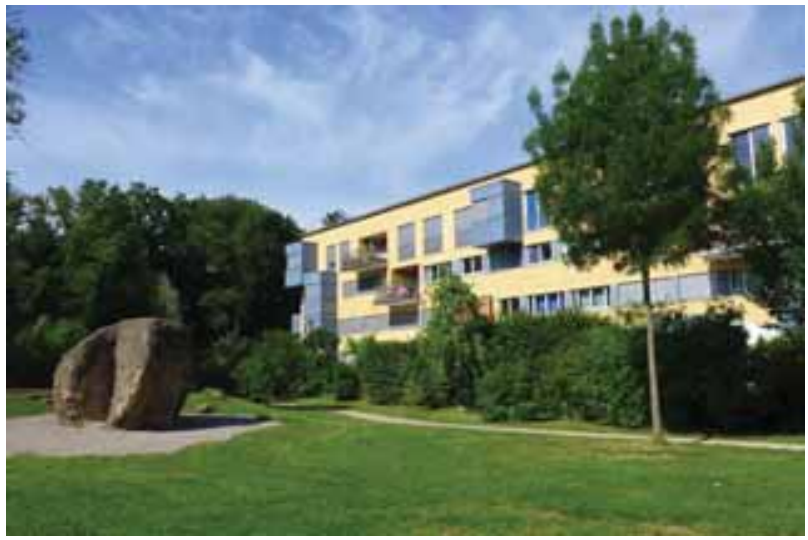

Figure 10: Baugruppe housing along resident designed park. 


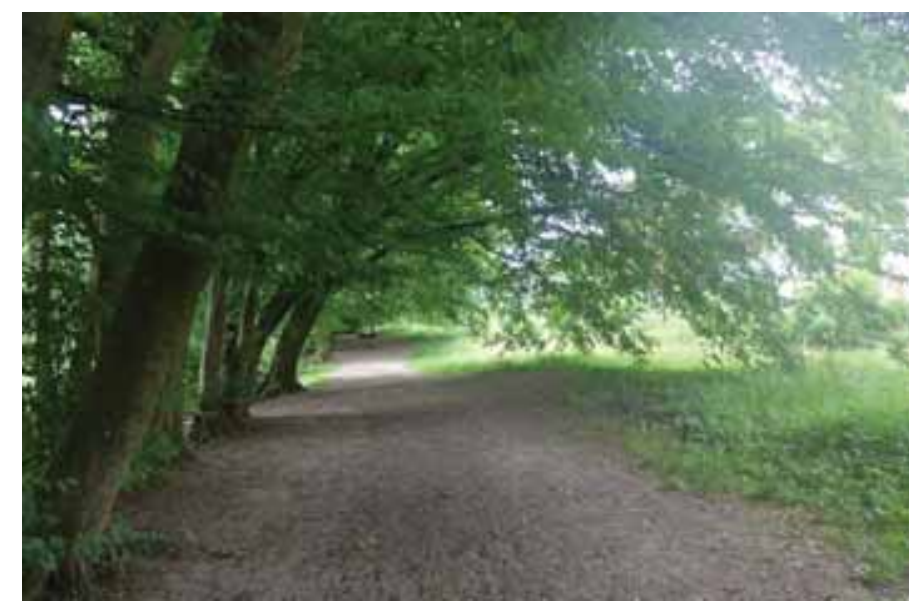

Figure 11: Path along Dorfbach Creek at southern edge of Vauban.

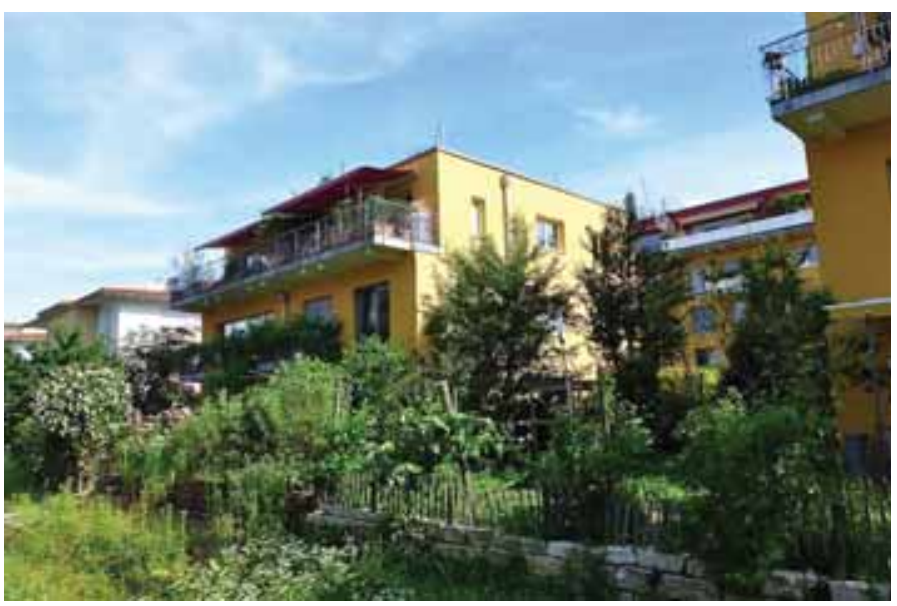

Figure 12: Passive solar houses along the Dorfbach Creek walking path.

Vauban has four kindergartens and the Caroline-Kaspar-Schule, a primary school, which is also designed to be used as a community meeting center. In front of this school is Paula-ModersohnPlatz, which connects the school to a major transit stop as well as a grocery store and other businesses along Merzhauserstrasse (Figs 13 \& 14). Thus, children in Vauban are placed in the middle of urban life as well as being offered a variety of green play spaces and more remote natural areas.

\subsection{The solar settlement at Schlierberg}

Finally, to the east of Merzhauserstrassse at the foot of Schönberg hill, is the colourful Sonnenschiff ('Solar Ship') and Solarsiedlung ('Solar Settlement'), designed by architect Rolf Disch. The entire district, which is designed to passive house standards, produces more energy than it consumes by means of rooftop photovoltaic panels, making this a Plusenergie ${ }^{\circledR}$ (Plus Energy) community (Figs 15-17). The commercial block Sonnenschiff lines Merzhauserstrasse and protects the 58 two- 


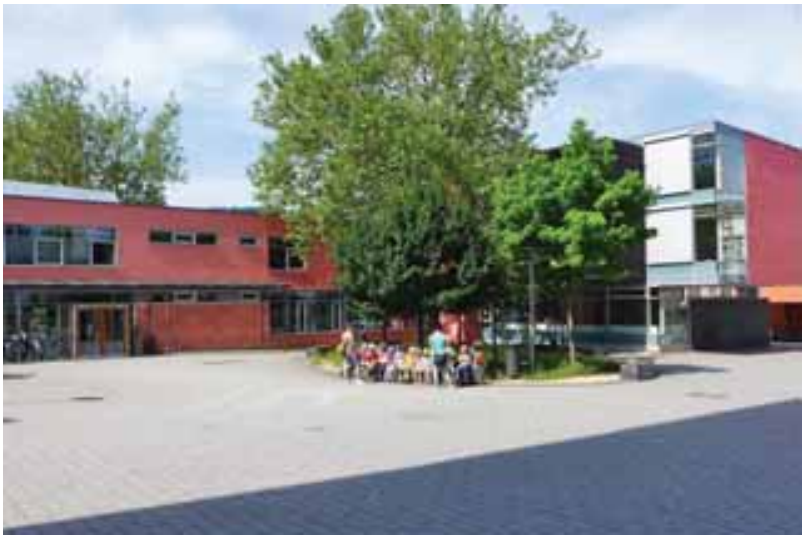

Figure 13: Caroline-Kaspar-Schule and Paula-Modersohn-Platz.

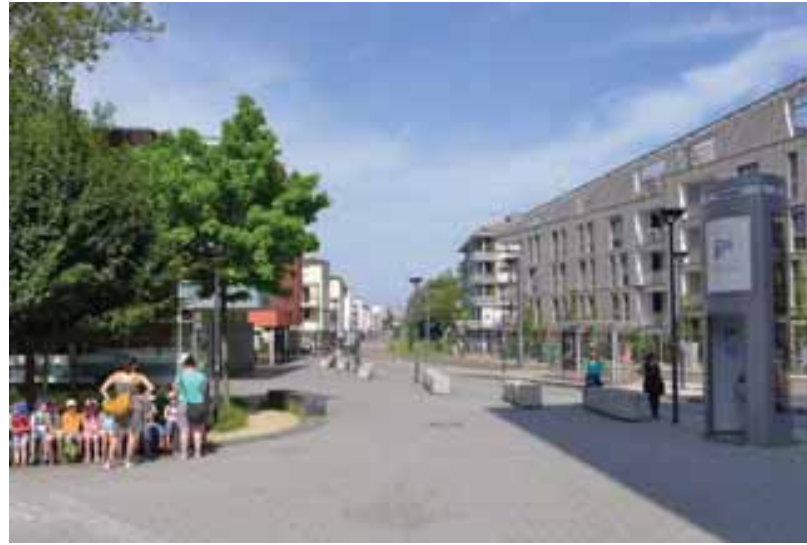

Figure 14: Paula-Modersohn-Platz and light rail stop.

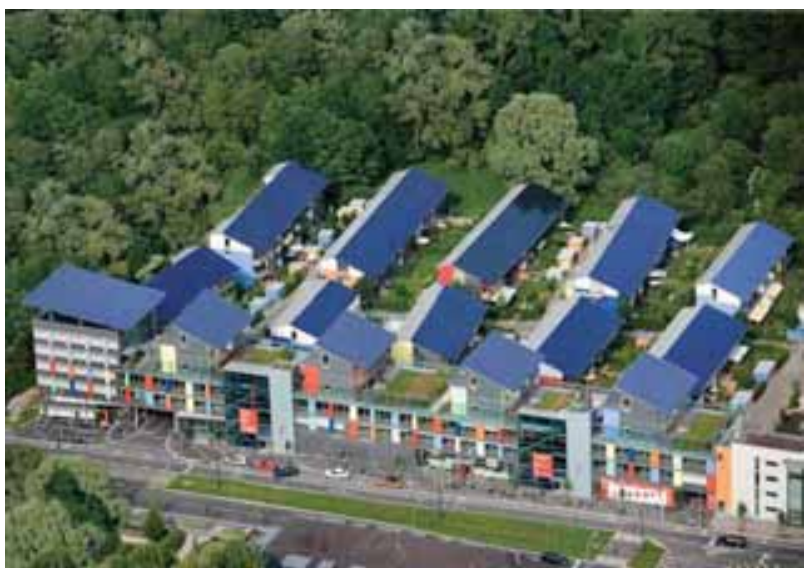

Figure 15: Plusenergie ${ }^{\circledR}$ Solarsiedlung am Schlierberg. 


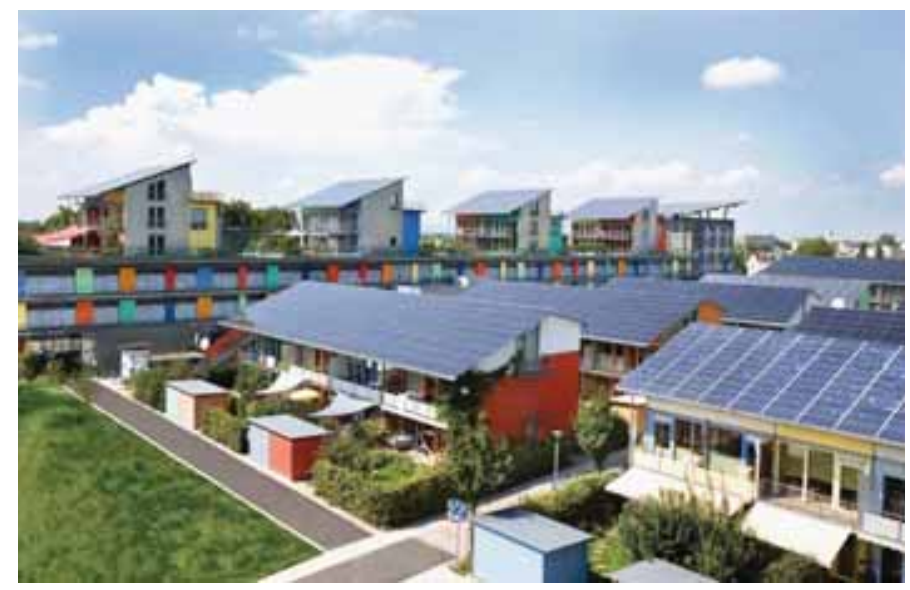

Figure 16: Sonnenschiff viewed from the Solarsiedlung.

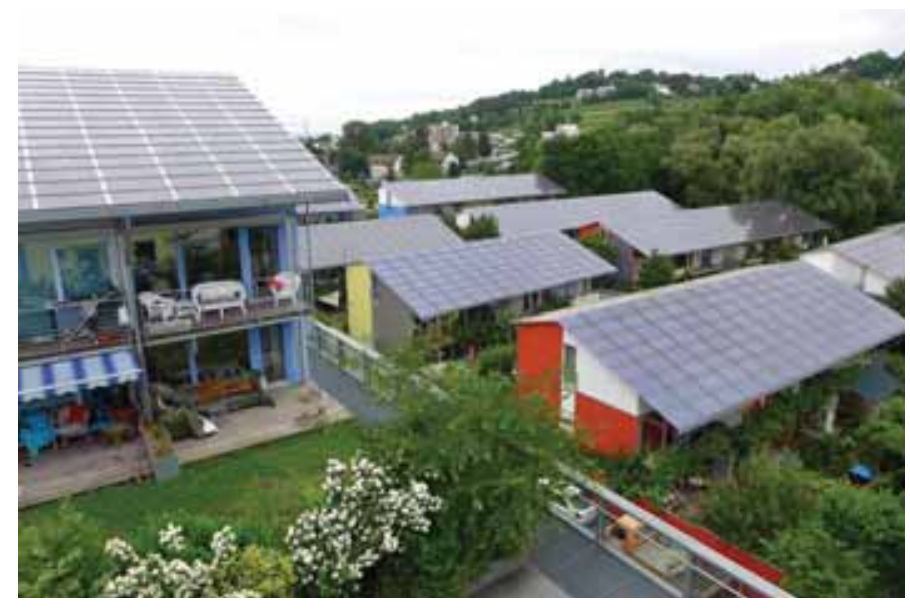

Figure 17: Solarsiedlung, view from Sonnenschiff penthouse.

to three-storey row houses from street noise. It is occupied on the ground floor by a bank and a variety of retail enterprises, such as an organic grocery store and a pharmacy. Offices, including that of Rolf Disch, Architects, are located on the upper floors. The structure is topped with four threestorey passive solar penthouses, opening onto gardens and terraces facing south [7].

\section{THE TRANSPORTATION CONCEPT: 'CAR-FREE' LIVING}

While the goal of becoming 'car-free' has not been completely achieved, Vauban is widely recognized as a pioneer of 'car reduced' urbanism. As of 2009 around $70 \%$ of households have chosen to live without owning a car [8]. Eighty-one percent of these car-free residents report that everyday life without a car in Vauban is easy or very easy and $96 \%$ of these residents say that they have not even thought about buying a car. In one study, with a $32 \%$ response rate, more than $38 \%$ of respondents reported that they use a bicycle more than they did before moving to Vauban and more than $27 \%$ 
walk more often than they did when they lived elsewhere. Vauban residents remain pleased with these policies and their effects on the quality of life in the district. These positive outcomes have been achieved as a result of design decisions as well as innovative policies that offer both incentives for car-free living as well as penalties for car ownership [9].

\subsection{Transport policies}

Parking is only allowed on Vaubanallee, in part to support retail enterprises along this main street (Figs $6 \&$ 7). Otherwise, residents who do own cars are required to park them in one of the two garages, which are located at the northern and eastern edges of the district. Both garages are covered by arrays of photovoltaic panels producing significant amounts of electricity.

Parking is not allowed in front of dwellings on the narrow residential streets (Fig. 9). This policy required a change in Baden-Würtemberg's laws, which require builders to provide one parking space on-site for each residential unit. While it took years of negotiations, the law was changed to permit residents of Vauban to live in car-free districts on two conditions: (1) residents (or future residents) have to agree that they do not and will not own a car and (2) Vauban must certify that there is land dedicated to parking if the resident chooses to own a car.

The Vauban Club for Car-Free Living was established to make sure that these requirements would be met. Once a member signs a commitment to remain car-free and pays a membership fee of 3,700 Euros, the city issues a building permit for their residential unit. If the members of the club decide later to purchase a car, they must pay more than 15,000 Euros to the Club, which is the cost of constructing a parking space in one of the garages. In addition, residents owning a car must pay monthly rental fees and their share of annual property taxes levied on the garages. The penalty for purchase of a car without notifying the city can be as high as 100,000 Euros [9].

Thus, in Vauban, automobile users are required to pay for the actual costs of a parking space, and car-free households are rewarded for choosing to live car-free [10]. Given these policies it is not surprising that car ownership in Vauban is only 150/1,000 compared with 430/1,000 in Freiburg as a whole and 630/1,000 in the United States [11].

Car-free residents can, however, have access to cars when they need them by becoming members of The Freiburger Auto Gemeinschaft, a car sharing club which makes available five cars and a van parked in one of the district's garages. Club members also receive a free pass for all forms of public transit in Freiburg and as well as a Bahncard giving them 55\% off on every train ticket, making public transit even more attractive and affordable [12].

\subsection{Urban design}

Vauban's 'car-free' policies would have been onerous and unworkable if its design did not completely support them. The district is a high-density, compact, mixed-use community, which means that every trip within it is short, whether on foot or by bike. In addition, through the use of the principle of 'filtered permeability', expressed through a 'fused grid' street layout, it is much easier and less time consuming to shop locally for everyday needs by walking or bicycling than it is to use a car (if you even have one) [13]. While there are discontinuities of access for cars, the network of walking and bicycling paths permeate every part of Vauban and connect directly to the rest of Freiburg.

Light rail service, which began in Vauban in 2006, has three stops in the district (Fig. 18). With trams running 8-10 times per hour during periods of peak demand, residents of Vauban are only 13 min from the city center and $18 \mathrm{~min}$ from the central train station. There are also bus stops at two of 


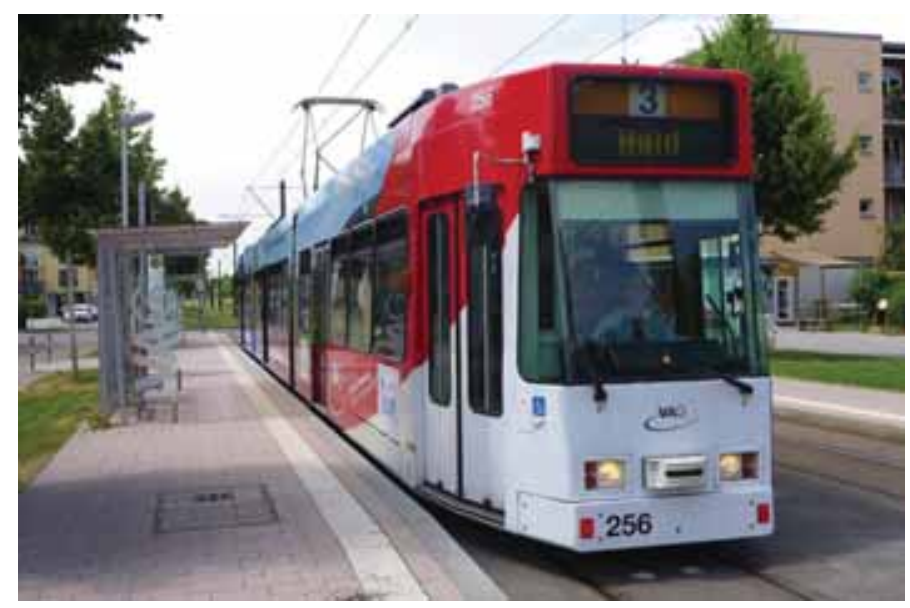

Figure 18: Vauban station with light rail and bus connections.

the light rail stations in the district and interchange connections by bus and rail allow access without a car to any part of the city, the region and beyond.

\section{BAUGRUPPEN: A NEW MODEL FOR COMMUNITY DEVELOPMENT}

Working closely with the city, Forum Vauban helped identify and organize Baugruppen, small legally constituted cooperatives comprised future homeowners committed to designing and developing their own communities. A Baugruppe could be formed in one of the two ways: a group of citizens could apply to the city to develop a site or the city could announce its desire to develop a district using Baugruppen, along with a call for expressions of interest. To be viable, a Baugruppe had to have between 10 and 50 families [14].

From the beginning, priority for residential development was given to private homeowners and Baugruppen, rather than investor developers, who, in any case, showed little interest at the time in participating in a project that was seen as too radical with regard to energy use standards, ecological design and 'car-free' living.

To make land cost more affordable for Baugruppen and individual households, the majority of housing sites offered by the city were small. In addition, the city was required to declare up front the purchase price of the land. Certainty regarding land costs allowed citizens to know how much they would have to borrow before they even formed a Baugruppe. This policy also prevented large investor developers from entering a bidding war that would make land costs unaffordable for smaller developers. Thus, rather than allocating land based on maximizing the sale price, the city evaluated the ability of the various Baugruppen to successfully meet the lofty sustainability goals of the district. The question now became: 'How can the sale of this land best suit the goals of the project and the needs of its future residents?' rather than, 'How can the city make the most money from land sales?'

Considerable design freedom was afforded to Baugruppen as long as their proposals maintained required overall densities, kept below height limits and ensured that minimum energy use standards would be met. Including all three phases of development between 1998 and 2009, more than 45 Baugruppen developed the majority of the housing in Vauban. The use of this approach resulted in an estimated cost savings for participating homeowners of $25 \%$ or more compared with conventional profit-oriented commercial development [15]. 
Baugruppen are largely responsible for the architectural diversity, human scale, and sense of place and community that characterize the district. These qualities are exemplified by the following Baugruppen case studies.

\subsection{Genova: social and ecological goals}

Founded in 1997, the intention behind this Baugruppe was to combine ecological and social goals to create affordable and flexible housing for a variety of household types and age groups (Figs 19 \& 20). They built 36 units in the first phase of construction and another 40 units in the second phase. Through workshops, a co-operative council and representatives on the management team, residents participated intensively in all aspects of the process, from the design of individual apartments to the design of facades, energy systems and the ownership and self-management structure.

The Genova project has clearly met its energy and ecological goals. It has better energy performance than the minimum standards for Vauban; a large solar hot water installation; rainwater cisterns

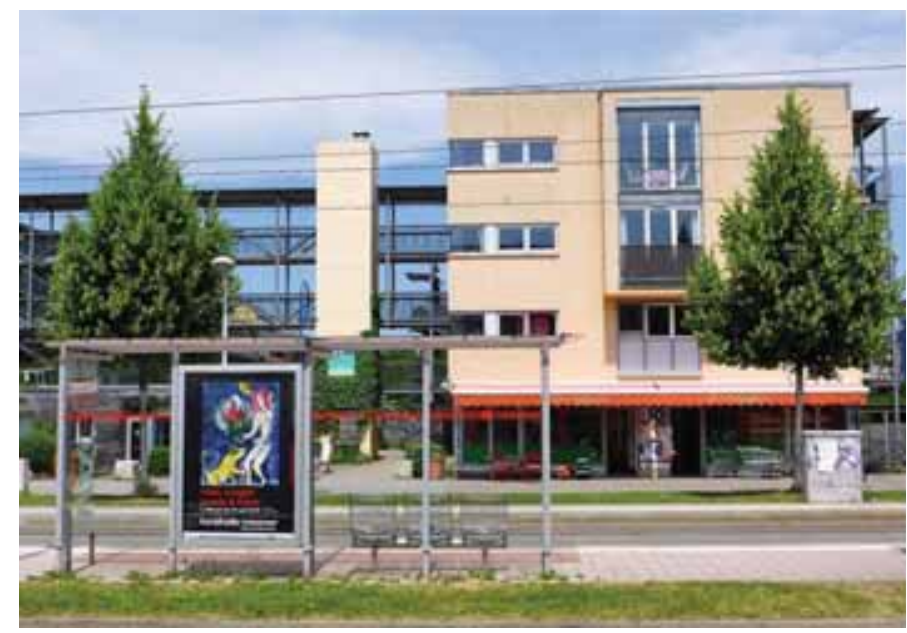

Figure 19: Genova phase 2 located along Vaubanalleé.

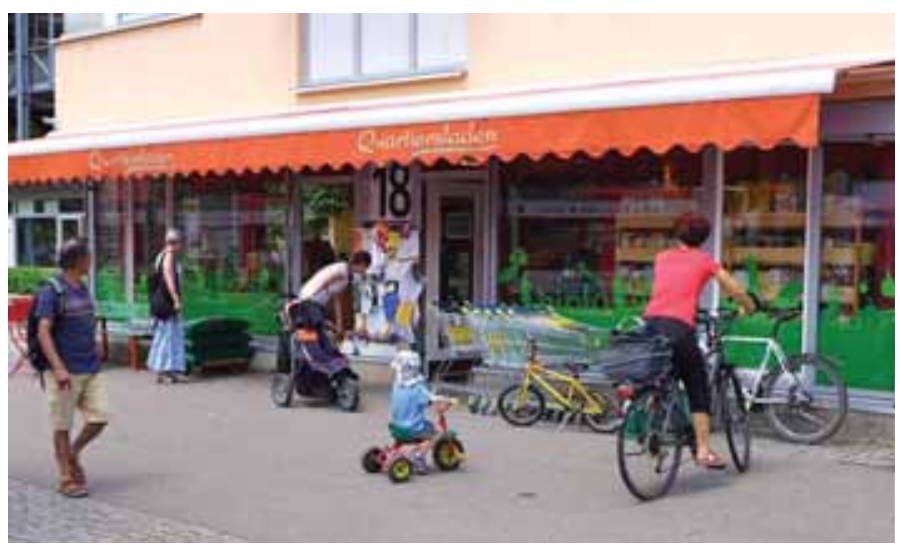

Figure 20: Whole foods store operated by Genova on Vaubanallee. 
for use in the gardens; green roofs; floors built with locally harvested wood and non-toxic materials and finishes. In phase 1, 35 of 36 households were car-free. With regard to social goals, Genova is: the largest project in Vauban with apartments for rent; a multi-generational barrier-free community with an elevator and exterior galleries providing access to the great majority of dwelling units. To encourage a sense of community, Genova also has shared guest rooms, a shared clothes washing and drying room, a communal house and garden, and a popular whole foods store on the pedestrian/ bicycle lane that runs along Vaubanallee (Fig. 20) [16].

\subsection{Sonnenhof: Woge and Arche (2008)}

Another example of the kind of innovation and creativity that the Baugruppe process has given rise to in Vauban is Sonnenhof ('Sun Court'). A central organizing idea for this development was that a truly living community should include humans and their domestic pets as well as people of all ages, incomes and abilities, all of whom are committed to helping each other (Fig. 21). To realize this intention, Sonnenhof was designed as a mixed-use community comprising an office block and a total of 30 dwelling units. Arche (the Ark) has 13 small subsidized apartments for elders and single parents with children. Woge (the Wave) is a self-contained residential wing for 10 residents with dementia. The remainder of the units is market rate condominiums for larger households with children.

These three elements of the Sonnenhof community are integrated around a central courtyard, with the bar containing offices facing Lise-Meltner-Strasse to the south and a U-shaped residential component on the north connecting to this bar (Fig. 22). The dementia wing (Woge) forms the western edge of the courtyard and has a secured outdoor garden facing west (Fig. 23). From this courtyard, it is also possible to see the garden play space of a kindergarten to the north as well as pedestrians, bicyclists and automobiles using Lise-Meltner-Strasse to the south. Each of the 10 bedrooms in Woge has a window that faces either this garden or the Sonnenhof courtyard to the east.

As a result of this layout, residents with dementia are visually connected to both the larger Sonnenhof community as well as the surrounding Vauban community. Children from the nearby

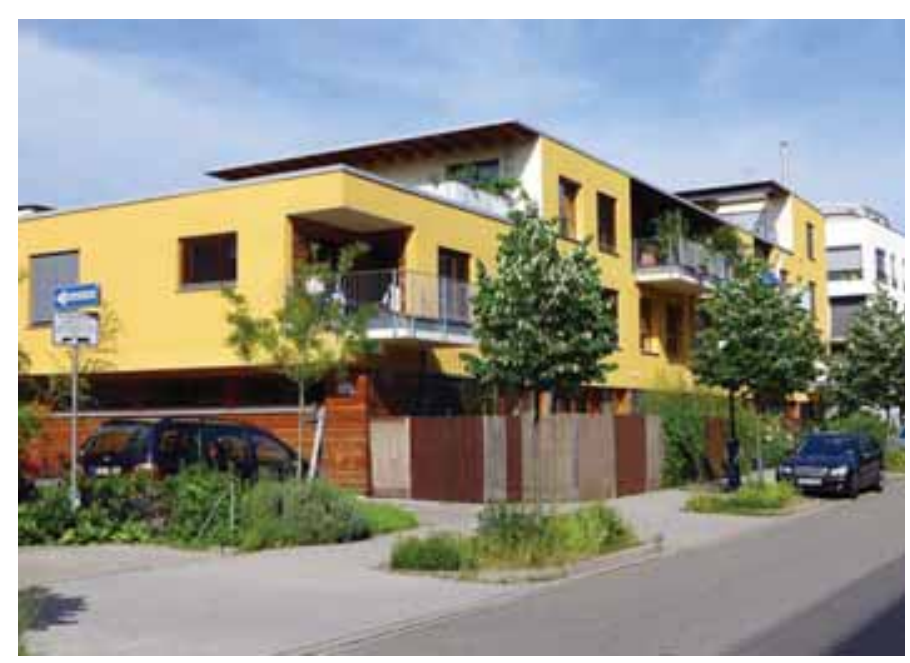

Figure 21: Sonnenhof viewed from Lise-Meltner-Strasse. 


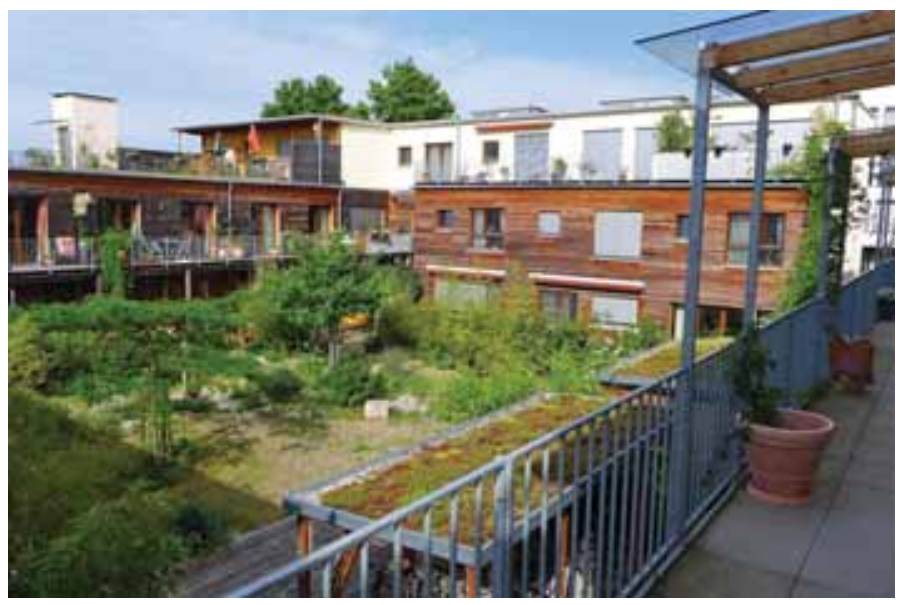

Figure 22: Sonnenhof courtyard viewed from the office block.

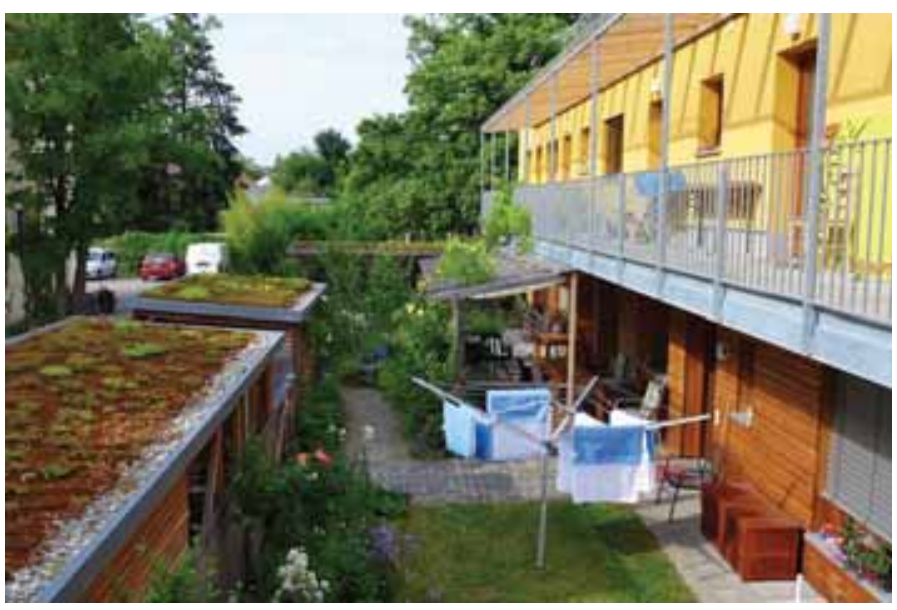

Figure 23: Garden for residents with dementia.

kindergarten, volunteers and family members, a number of whom live in Vauban, make sure that residents are also functionally, as well as visually, integrated into the world beyond by visiting Woge on a regular basis. In Sonnenhof, the architecture and the programmes for support and care were designed together as a single unified whole to create a nurturing community for all residents, including their beloved pets [17].

\subsection{Passivhaus Wohnen and Arbeiten (1999)}

This multifamily housing block was one of the first projects in Vauban to be developed by a Baugruppe. It is the brainchild of architect Michael Gies of Common + Gies Architekten, who wanted to build a multi-family Passivhaus, and biologist Dr. Jörg Lange, who wanted to implement a radically new 
concept for handling water and waste in buildings [18]. While it proved impossible to fully implement, this vision of a 'house without a chimney, without a link to the grid and without a link to the district sewage system' readily attracted prospective homeowners to the Baugruppe [19]. It also peaked the interest of Dr. Martin Ufheil of the Fraunhofer Institute for Solar Energy Systems in Freiburg, as well as Dr. Wolfgang Feist of the Passivhaus Institute in Darmstadt, Germany. The technical assistance of both of these experts was instrumental in the development of this precedent-setting building design [20].

\subsubsection{The energy concept}

The goal for energy use was the Passivhaus standard of $15 \mathrm{kWh}$ per square meter per year or less. The measured thermal performance, which exceeded this goal, was made possible because the building incorporates five necessary and interrelated elements for Passivhaus design: (1) airtight construction with very high levels of resistance insulation in light weight timber framed external walls; (2) triple-glazed windows with two heat reflecting surfaces; (3) a simple building volume with large south facing windows for winter solar gain and four large Linden trees that shade these windows during the summer (Figs $24 \& 25$ ); (4) a mechanical ventilation system that preheats incoming fresh air by passing it by the warm outgoing air and (5) the capture of internal heat gains from people, appliances and lights [18].

The high thermal mass construction used for interior walls and the precast concrete floors absorb and store solar energy from south-facing windows and, in the summer, provide cooled mass as a result of night-time flush ventilation. A small natural gas powered CHP (12 kWh peak) unit, supplemented by roof top photovoltaics $(3.2 \mathrm{~kW}$ peak), provides $80 \%$ of the electrical needs. Fifty square meters of rooftop solar hot water heaters, combined with hot water from the CHP system, provide all of the space and water heating for the building. This project demonstrates that it is possible to achieve a $79 \%$ reduction in primary energy use, including electrical power, with only a modest $7 \%$ increase in initial construction cost. Altogether, this building reduces greenhouse gas emissions by $80 \%$ compared with conventional new construction [21].

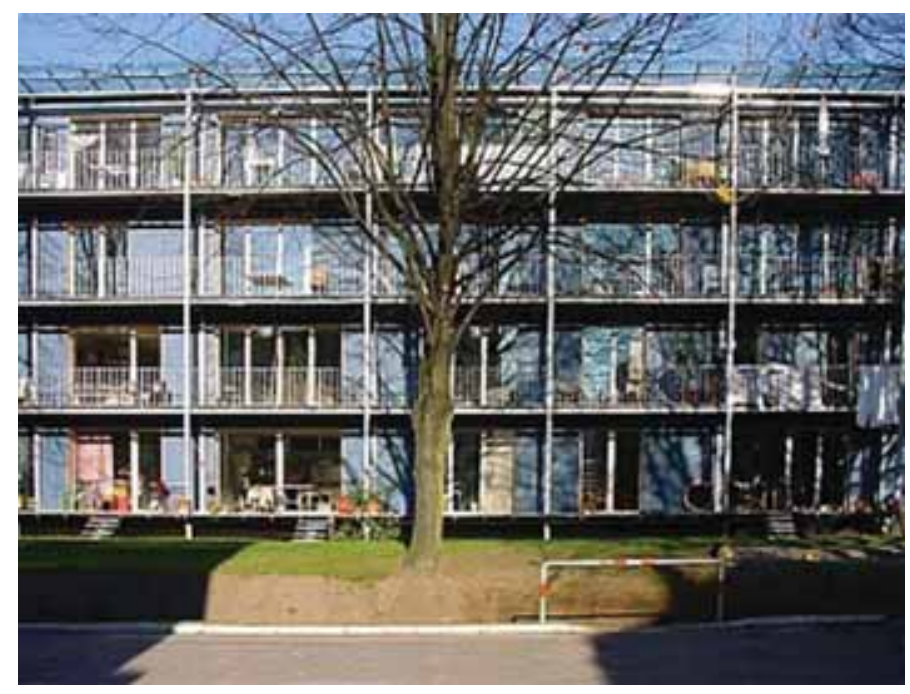

Figure 24: South elevation in winter. 


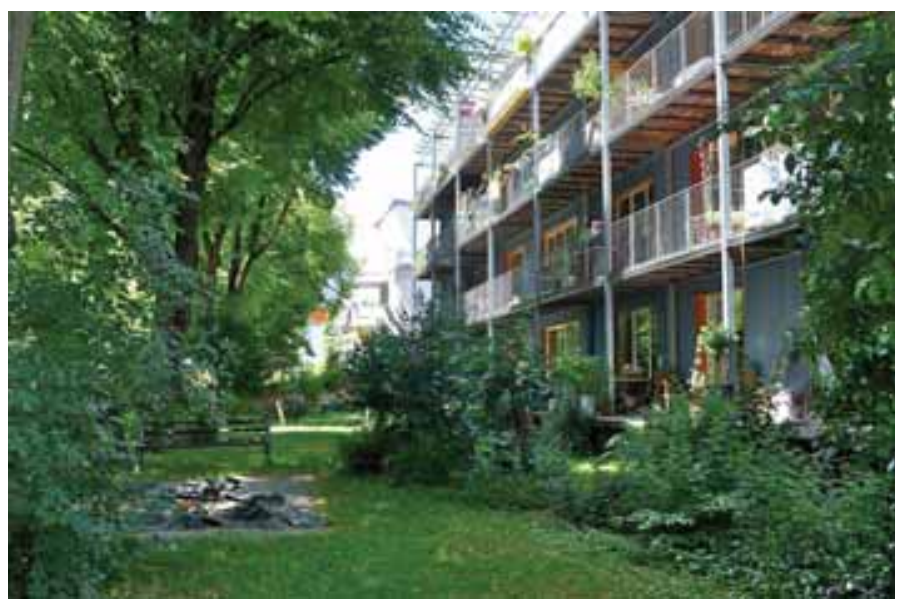

Figure 25: South elevation in summer.

\subsubsection{The water and waste concept}

Dr. Jörg Lange's vision was for a 'wastewater free' house, in which organic and human waste would become a source of energy and recovered nutrients rather than merely a costly pollution problem. Vacuum toilets, which reduce the water usage by nine tenths, were installed to transport human waste to an anaerobic biogas digester, which produces liquid fertilizer (high in recovered phosphorus) as well as biogas to be used for cooking. Grey water from showers, dishwashers and sinks is re-used after being cleansed in aerated sand filters and treated with UV rays. Rainwater flows through gutters into bio-swales with gravel substrata, where it is filtered before leaching into the groundwater.

While the biogas reactor has never been operated because the manufacturer went bankrupt, subsequent research has shown that it is a workable system [22]. Perhaps, this system may yet go into use in Wohnen and Arbeiten or another building like it [23].

\subsubsection{Wohnen and Arbeiten dwelling design}

The architect worked closely with Baugruppe members to custom design each of the 16 apartments and the 4 offices, while still keeping a simple overall building volume [24]. Apartments have windows on both the north and south for balanced light and natural ventilation. Each unit is entered from outdoor walkways on the north (Fig. 26). The open plan units on all four floors are capable of being rearranged to suit changing needs. Apartments range from one-room studios to three-bedroom family units. Most units are contained on a single floor but some have internal stairs and spaces on two floors. Each unit opens onto a south-facing balcony, which provides a sunny outdoor place in the winter while shading the solar glazing during the overheated season. Technical equipment and a communal laundry are located in the basement. The four-storey height was set in order to avoid the need for an elevator [24].

In Wohnen and Arbeiten energy, as well as water and waste systems, were designed to create a holistic, integrated ecological design and cohesive living community. Altogether, this project was a pioneering attempt to define a new paradigm for sustainable building design that attracted worldwide attention and informing and inspiring similar designs, including Kleehäuser, a 25-unit handicapped accessible multi-generational housing project built in Vauban in 2006, which was also designed by architect Gies (Fig. 27). Using a combination of design techniques and energy systems 


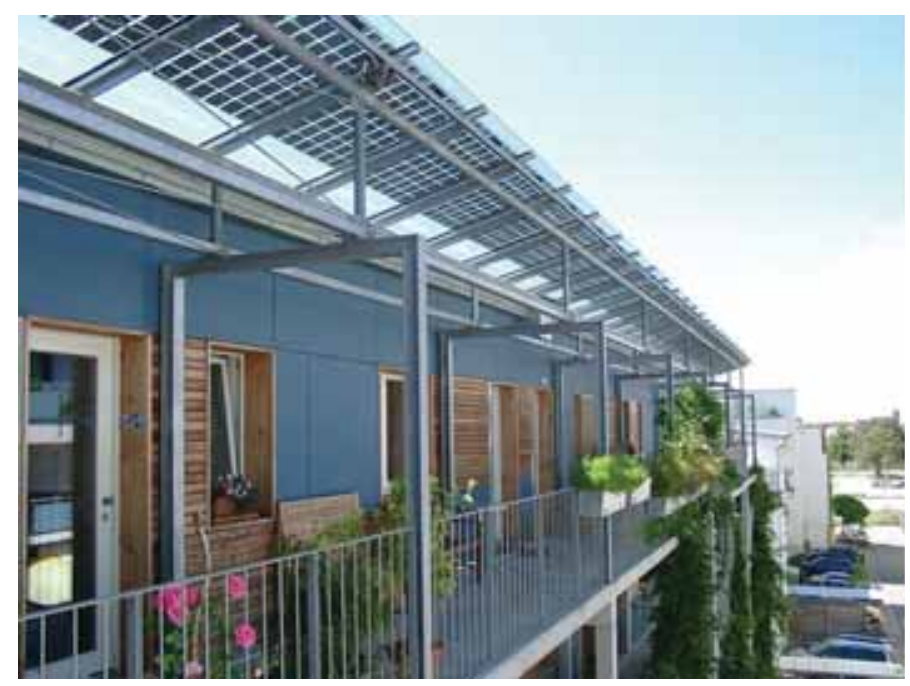

Figure 26: Each apartment is entered from walkways on the north.

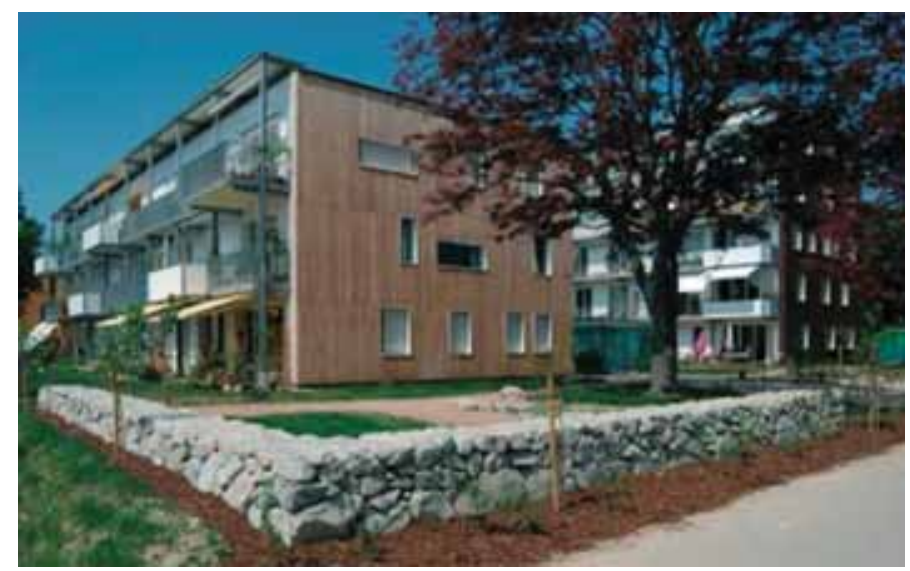

Figure 27: Kleehäuser viewed from the south. Photo by Jörg Lange.

successfully applied in Wohnen and Arbeiten, as well as the purchase of carbon emission credits from a nearby wind farm, Kleehäuser has been able to meet the stringent Swiss 2,000 Watt Society requirements to create an energy-efficient, zero carbon building [25].

\section{VAUBAN: TOWARD A NEW PARADIGM FOR SUSTAINABLE URBAN DEVELOPMENT}

What is meant by the term 'sustainable urban development' and how can we judge whether Vauban or any other development is, in fact, 'sustainable'? [26] At the end of October 1999, an international conference (InnerVisions) was held in Freiburg. Attended by 100 participants from 21 European nations, it was sponsored by Forum Vauban and the International Council for Local Environmental 
Initiatives in order to explore these and related questions. A summary document from this gathering called, 10 Theses for Sustainable Urban Development, was presented at Urban 21, a global conference held in Berlin in July of 2000. These 10 Theses constitute a holistic and comprehensive framework that can be used to assess the success of Vauban or any other present or future sustainable urban development [27].

\section{The sustainable city:}

\section{(1) Promotes an integrated planning culture}

From the beginning, Vauban involved city administration, local politicians, technical experts and representatives of citizen groups in the design and development of the district through a flexible and transparent process of continuous learning and 'responsive planning'.

\section{(2) Makes use of new forms of citizen participation}

Participation can range from the manipulative and tokenistic to the functional and interactive [28]. In Vauban, the Baugruppen-based process assured that citizens were interactive partners with the city and, as the primary housing developers, that their participation would be real and consequential.

\section{(3) Implements sustainable transport and mobility concepts}

Innovative transport policies complement physical design to make it possible for residents to live 'car-free' in Vauban, setting a precedent for all future sustainable urban districts.

\section{(4) Promotes environmentally sound and healthy building measures}

The city of Freiburg established minimum standards for energy use, building quality and ecological landscape design that, in nearly every case, were exceeded by the housing developed by Baugruppen.

\section{(5) Has an ecologically sound energy supply and minimizes energy consumption}

Energy conserving and renewable energy technologies at all scales of environment make Vauban one of the most successful low energy and renewable energy powered urban districts in the world.

\section{(6) Strengthens regional economies}

By making use of technical experts from Freiburg and the surrounding area, as well as local energy supply and construction services, Vauban has solidified Freiburg's position as the solar capital of Europe. In addition, the businesses created in the district itself have further strengthened the local Freiburg economy.

\section{(7) Designs socially oriented living spheres}

Because of the initiatives of the Baugruppen, SUSI and students, the district has a diverse population, even though it is now dominated by college-educated families with children. Vauban also has a variety of social and cultural facilities, places of education, shopping and recreational areas. In Vauban, nature is always near and the community is thoroughly child-friendly.

\section{(8) Mixes requirements with supporting measures}

The radically participatory approach to urban development used in Vauban unleashed a process of social, ecological and architectural creativity that went well beyond the already bold sustainability requirements of the city. This managed market approach, which integrated 'bottom up' and 'top down' approaches to planning and design, proved to be uniquely valuable and successful [29].

\section{(9) Cultivates good contacts and exchange of experiences}

From the beginning of planning for the district, city officials, technical experts and engaged citizens have communicated with interested groups and individuals at the regional, national and 
international levels about Vauban's goals, methods and outcomes. Tours and presentations continue for tens of thousands of visitors who visit Vauban every year.

\section{(10) Has the courage to leave the beaten track}

The city and individual Baugruppe have pushed the envelope on what it means to design, build and live in a renewable energy powered sustainable city. While still falling short of its most ambitious dreams, the district has pioneered a new paradigm for the collaborative development of sustainable communities.

\section{CONCLUSIONS}

As measured by the 10 Theses for Sustainable Urban Development, it is clear that Vauban is remarkably successful. It is also clear that this district is the result of a unique set of historical circumstances, in which the flush of optimism that arose out of the collapse of the Soviet Union and the re-unification of Germany, met an acute need for new housing in one of the world's most democratically oriented and environmentally conscious cities.

Thus, in conclusion, it must be asked whether Vauban is unique to the circumstances that gave birth to it, or is it a model that can be replicated elsewhere in the world, or even in Freiburg itself, which is currently planning new districts to meet a rapidly growing housing demand. Even among those who were primary actors in creating Vauban, there is significant disagreement on this question. Some believe that the citizens of Freiburg are no longer passionate enough about citizen participation and sustainable design to counter the investor developers, who are now lining up to profit from building the next 'sustainable community'. Others believe that Freiburg can and will build upon what has been learned in Vauban (and Rieselfeld) about both citizen participation and sustainable design, and that the city will succeed in creating even more beautiful and livable mixed-use urban communities in the future. Only time will tell.

\section{ACKNOWLEDGEMENTS}

I thank the following interviewees who provided me with important information and insights regarding the development of Vauban: Reinhard Böwer, Ludwig Eith and Hela Murken, architects and Vauban residents; Dr. Tobias Bube, office of Rolf Disch Architects; Reinhard Huschke, Vauban Baugruppe resident; Michael Gies, architect and Jörg Lange, biologist and Baugruppe resident of Vauban. Professor Susanne Siepl-Coates rendered invaluable service by providing translations as needed during interviews as well as translations of selected texts.

\section{REFERENCES}

[1] Frey, W., Freiburg Green City: Approaches to Sustainable Urban Development, Herder: Freiburg Basel Wien, p. 102, 2011. For an excellent overview of Freiburg as 'the European capital of environmentalism', with discussions of both Rieselfeld and Vauban, see: GauzinMüller, D., Sustainable Architecture and Urbanism: Concepts, Technologies, Examples, Birkhäuser: Basel Berlin Boston, pp. 69-75, 2002.

[2] Frey, W., ibid., pp. 103-107.

[3] Frey, W., ibid., pp. 108-113.

[4] See Field, S., 'Vauban: Freiburg, Germany', in Foletta, N. and Field, S., Europe's Vibrant New Low Car(bon) Communities, downloadable PDF available at, www.itdp.org/news/europesvibrant-new-low-carbon-communities.

[5] Frey, W. ibid., pp. 109-110. Over the course of nearly two weeks living in Vauban in the summers of 2012 and 2013, the author personally experienced the effectiveness of these greenways as ventilation corridors bringing cooling breezes into the heart of Vauban. 
[6] For a consideration of the importance of integrating nature in architecture and urban design see: Kellert, S. R., Heerwagen, J. H., \& Mador, M. L., Biophilic Design: the Theory, Science, and Practice of Bringing Buildings to Life, John Wiley \& Sons, Inc. 2008. See also: Louv, R., The Nature Principle: Reconnecting with Life in a Virtual Age, Algonquin Books of Chapel Hill: Chapel Hill, North Carolina, 2012.

[7] Guzowski, M., Towards Zero Energy Architecture: New Solar Design, Laurence King Publishing LTD: London, United Kingdom, pp. 52-67, 2010.available at : http://www.werkstatt-stadt. de/en/projects/22/

[8] http://en.wikipedia.org/wiki/Vauban,_Freiburg

[9] http://streetswiki.wikispaces.com/Quartier + Vauban, http://www.forum-vauban.de/verkehrskonzept.shtml

[10] Shoup, D., The High Cost of Free Parking, APA Planners Press, updated edition 2011.

[11] de Pommereau, I., 'New German community models car-free living', The Christian Science Monitor, December 20, 2006. available at http://www.csmonitor.com/2006/1220/p01s03woeu.html

[12] http://www.solaripedia.com/13/95/845/vauban_map_(germany).html

[13] op. cit., http://en.wikipedia.org/wiki/Vauban,_Freiburg. See also op. cit., http://streetswiki. wikispaces.com/Quartier + Vauban. Also see 'The Fused Grid: A Contemporary Urban Pattern', available at http://www.fusedgrid.ca/fusedgrid.php

[14] Little, J., 'Lessons Learned from Freiburg on Creating a Sustainable Urban Community' available at http://www.feasta.org/forum/files/baugruppe_essay_rev_270508_199.pdf

[15] 'Vauban, Germany: Community leadership delivering sustainable urban renewal', available at http://www.sustainability.vic.gov.au/resources/documents/business_models_for_enabling_ sustainable_precincts_case_study_vauban.pdf

[16] 'Benchmark Study: European Sustainable Urban Development Projects', available at http:// www.secureproject.org/download/18.360a0d56117c51a2d30800078420/Vauban_Germany. pdf, available at http://webarchive.nationalarchives.gov.uk/20110118095356/http:/www.cabe. org.uk/case-studies/vauban/team

[17] http://www.diearche-freiburg.de/arche-im-sonnenhof/

[18] www.passivhaus-vauban.de

[19] Frey, W., Freiburg Green City, op. cit., p. 127.

[20] Interview with Michael Gies and Jörg Lange, in Vauban June 21, 2013.

[21] Gauzin-Müller, D., Sustainable Architecture and Urbanism: Concepts, Technologies, Examples, op. cit., p. 156.

[22] Frey, W., op. cit., p. 128.

[23] Interview with Jörg Lange in Vauban June 21, 2013.

[24] Interview with Michael Gies in Vauban June 21, 2013.

[25] Voss, K. \& Musall, E., Net Zero Energy buildings: International Projects of Carbon Neutrality in Buildings, Detail Green Books, p. 84, 2013. available at, http://bruteforcecollaborative. com/wordpress/2010/06/12/phbdw-passivhaus-bau-der-woche-02/ and http://en.wikipedia.org /wiki/2000-watt_society

[26] It is widely recognized that Germany is one of the leading nations in the western world with regard to the movement to create a sustainable society. The urban district of Kronsberg in Hannover is an admirable example of sustainable urban design architecture even though it was not created through a 'bottom-up' process of design and development by Baugruppen as was the case in Vauban. For a description of Kronsberg see: Gary J. Coates, 'Sustainable Urbanism: Creating Resilient Communities in the Age of Peak Oil and Climate Destabilization', in 
Wallimann, I. (ed.), Environmental Policy is Social Policy-Social Policy is Environmental Policy: Toward Sustainability Policy, New York, Heidelberg, Dordrecht, London: Springer, 2013, pp. 81-101, and; Gary J. Coates, 'The City as Garden: A Study of the Sustainable Urban District of Kronsberg (Hannover), Germany', in Documentation Set \# 57: Sustainability Issues Shape Planning: Selected from presentations at the International Making Cities Livable Conference, IMCL Council, 2009. available at http://www.livablecities.org/documentationsets/ 57-sustainability-issues

[27] http://www.forum-vauban.de/downloads/urbanvisions.pdf

[28] Scheurer, J., 'Urban Ecology, Innovations in Housing Policy and the Future of Cities: Towards Sustainability in Neighbourhood Communities', PhD Thesis, Murdoch University, Perth. As cited in Monika Anderson, Chapter 7: Community Participation available at www.istp.murdoch.edu.au/ISTP/casestudies/Euro_Field_Trip/eft2002-ch-7.pdf.

[29] http://www.sustainability.vic.gov.au/resources/documents/pro081_building_the_business_ case_vauban.pdf 